American Journal of Experimental Agriculture

12(4): 1-11, 2016, Article no.AJEA.24629

ISSN: 2231-0606

SCIENCEDOMAIN international

www.sciencedomain.org

\title{
Chronic Problems of Turkish Farmers
}

\author{
Zeynep Ozbilge $^{1 *}$ \\ ${ }^{1}$ Department of European Union Economics, Marmara University, Istanbul, Turkey.
}

Author's contribution

The sole author designed, analyzed and interpreted and prepared the manuscript.

Article Information

DOI: 10.9734/AJEA/2016/24629

Editor(s):

(1) Anita Biesiada, Department of Horticulture, Wroclaw University of Environmental and Life Sciences, Poland.

(2) Anonymous.

Reviewers:

(1) Hasan Vural, Uludag University, Turkey. (2) Vecdi Demircan, Suleyman Demirel University, Turkey. (3) Usman Jimoh Michael, Federal College of Forestry, Ibadan, Nigeria (4) Roxana Piastrellini, Universidad Tecnológica Nacional, Regional Mendoza, Argentina.

(5) Anonymous, University of lowa, USA Complete Peer review History: http://sciencedomain.org/review-history/14617

Original Research Article

Received $27^{\text {th }}$ January 2016

Accepted $18^{\text {th }}$ April 2016

Published $13^{\text {th }}$ May 2016

\begin{abstract}
Turkish farmers who engage in soil cultivation have to face a number of serious problems, ranging from the loss of agricultural land to the climate change. Moreover, they cannot earn a living from agriculture due to high production costs, intermediation system in the trade of agricultural products and insufficient financial support. The price increases in chemical fertilizers range from $55 \%$ to $82 \%$ while the price increase in diesel oil is $47 \%$ in $2010-2014$ period. However, the increase in area based financial support is only $29 \%$ in the same period. Therefore, it is required that the state takes all measures to resolve problems of Turkish farmers. Preventing the misuse of agricultural land as well as its use for non-agricultural purposes, updating financial support for agriculture with respect to the price increases in agricultural inputs and developing a new agricultural policy which will focus on climate change are only some of the measures which should be implemented without delay in Turkey.
\end{abstract}

Keywords: Turkey; agriculture; constraints.

*Corresponding author: E-mail: ozbilgez@yahoo.com; 


\section{INTRODUCTION}

Since agriculture is an effective means of creating employment and income in developing countries along with providing food for everyone, it is an economic activity that cannot be given up. Evaluating some country examples, it is seen that capital formation in the agricultural sectors of developing countries contributes to their industrialization. For instance, the industrialization in Canada and the USA were realized as a result of the agricultural developments in these countries [1]. In this regard, agriculture and industry shouldn't be seen as "rivals". Instead, they should always be accepted as the "complementary" of each other as it is the case in developed countries.

On the other hand, the situation in Turkey has always been different. Agriculture in Turkey has always been ignored by the state at the expense of developing the industry. Despite being one of the countries with a huge agricultural capacity, Turkey cannot benefit from this opportunity. All of the existing problems in Turkish agriculture are a combination of the ignorance of agriculture at the state level along with the inability to use the capacity.

For this reason, this article aims at revealing the basic problems faced by Turkish farmers and offers solutions to them. However, the scope of this study is limited and therefore, Turkish farmers who engage in stock farming and fisheries are excluded. Besides, the study focuses on 2010-2014 time period.

\section{MATERIALS AND METHODS}

This study is based on the evaluation of relevant research articles with agricultural data to provide a better understanding of the farmer problems in Turkey. In this context, a literature review concerning farmer education and effects of climate change was made. Agricultural data used in the tables were obtained from the official websites of Turkish Statistical Institute and Turkish Ministry of Food, Agriculture and Livestock. Percentage values in tables, such as the changes in seed, chemical fertilizer and diesel oil prices, price differences that stem from the intermediation system in agricultural trade as well as the change in agricultural support were all calculated one by one and were used to highlight the most immediate farmer problems in Turkey.

\section{RESULTS AND DISCUSSION}

The decline in total agricultural land accompanied by small and fragmented pieces of agricultural land, high costs of agricultural inputs and inadequate financial support are among some of the chronic problems faced by Turkish farmers.

Farmers quit agricultural production on condition that the production cost of an agricultural product exceeds its selling price. However, the results of such a withdrawal may not always be so simple since it can create new problems, such as rural unemployment, migration and increasing food prices that trigger the inflation as it is the case in Turkey.

\subsection{The Loss of Total Agricultural Land in Turkey}

Regarding the fact that soil constitutes the backbone of agriculture and it is impossible to reproduce it, it becomes more important to use it sustainably. For this purpose, it is necessary to determine and categorize the pieces of land eligible for agricultural production to prevent them from misuse. The classification of land use capability (LUC) is the method used the most in determining types of agricultural land. There are eight categories of agricultural land in this method, the first four of which are accepted as "eligible for agricultural production" [2]. As shown in Table 1, total land that is accepted as "eligible for agricultural production" is $26,506,765$ hectares and it corresponds to $34.1 \%$ of the total area of Turkey. The highest share of total agricultural land is $9.5 \%$ of the fourth category whereas the lowest share belongs to the first category with $6.5 \%$. In other words, Turkey has limited capacity in terms of "first category topsoil" and has to take all the measures to prevent its loss.

Total utilized agricultural land is the sum of total arable land, total land under permanent crops beside land under permanent meadows and pastures. Examining Table 2, there is an increase in total land under permanent crops around $8 \%$ in $2010-2014$ period. On the other hand, the decline in total arable land in this period is $3 \%$ and it is the main contributor to the decline in total utilized agricultural land.

With respect to the decline in Turkey's total agricultural land, there are mainly two reasons that underlie this situation. The use of agricultural 
land for non-agricultural purposes, such as assigning agricultural land to industrial areas, housing zones, mining activities, tourist facilities and highway construction is the most widespread problem in Turkey. Furthermore, the misuse of agricultural land which leads to soil erosion as well as salinisation is another reason. Soil erosion is a serious problem since it affects $59 \%$ of the total arable land and $64 \%$ of the permanent meadows and pastures of Turkey [2]. According to a countrywide, soil survey in Turkey; 2.78 million hectares of agricultural land are affected by the problem of salinisation and drainage while 1.5 million hectares are affected by desertification [4].

\subsection{Small and Fragmented Pieces of Agricultural Land in Turkey}

There are two important points to take into account concerning the productivity and sustainability of an agricultural land. The first point is the fragmentation of an agricultural land which means that an agricultural enterprise is divided into many parcels and each parcel is found in another location [2]. With respect to the situation in Turkey, the land of agricultural enterprises is fragmented. The number of agricultural enterprises which are less than 5 hectares corresponds to almost $65 \%$ of the total number of agricultural enterprises whereas enterprises having more than 50 hectares only make up $0.7 \%$ of the total. The share of agricultural enterprises which are smaller than 5 hectares corresponds to $52 \%$ of the total number of parcels in Turkey.

Moreover, the average size of the agricultural land of an agricultural enterprise which is calculated by dividing total agricultural land to the total number of agricultural enterprises is another indicator of productivity [2].

As expressed in Table 4, the average size of an agricultural enterprise is only 6.1 hectares. In other words, "economies of scale" which is defined as "the larger the size or capacity is, the lower the costs are" cannot be implemented in the agricultural enterprises of Turkey. As a result, the use of technology in agriculture becomes more expensive, productivity remains stable and farmers give up agriculture [4]. The number of registered farmers in Turkey has decreased from 2,318,506 to 2,206,874 between 2010 and 2014, a decline that corresponds to $4.8 \%$ [6].

There are two basic laws regulating the use of agricultural land in Turkey. First of them is the "law of soil protection and use of agricultural land" which came into force on July 3rd, 2005. This law regulates the protection of the quality of agricultural land and its use for non- agricultural purposes. Agricultural land may be used

Table 1. The distribution of agricultural land in Turkey (According to LUC)

\begin{tabular}{llll}
\hline Category of land & Characteristic & $\begin{array}{l}\text { Total area } \\
\text { (in hectare) }\end{array}$ & $\begin{array}{l}\text { Share of } \\
\text { category (\%) }\end{array}$ \\
\hline 1 & $\begin{array}{l}\text { Eligible for all types of } \\
\text { agriculture and cultivation }\end{array}$ & $5,086,084$ & 6.5 \\
2 & $\begin{array}{l}\text { Eligible for cultivation } \\
\text { Limited eligibility for }\end{array}$ & $6,712,873$ & 8.6 \\
3 & $\begin{array}{l}\text { cultivation } \\
\text { Eligible for cultivating }\end{array}$ & 9.4 \\
& special products with & $7,425,763$ & 9.5 \\
4 & special measures & & \\
& & $26,506,765$ & 34.1 \\
Total $(1+2+3+4)$ & $77,839,707$ & 100 \\
Total area of Turkey & & & \\
\hline
\end{tabular}

Source: [2]

Table 2. The distribution of agricultural land according to its use in 2010-2014 period

\begin{tabular}{ccccc}
\hline Year & Total arable land & $\begin{array}{l}\text { Total land under } \\
\text { permanent crops* }\end{array}$ & $\begin{array}{l}\text { Land under permanent } \\
\text { meadows and pastures }\end{array}$ & $\begin{array}{l}\text { Total utilized } \\
\text { agricultural land } \\
\text { (in hectare) }\end{array}$ \\
\hline 2010 & $21,384,000$ & $3,011,000$ & $14,617,000$ & $39,012,000$ \\
2014 & $20,698,000$ & $3,243,000$ & $14,617,000$ & $38,558,000$ \\
\hline - Total land under permanent crops includes areas of other fruits, beverages, spices, vineyards and olive \\
trees. Source: [3]
\end{tabular}


by permission for other purposes, such as constructing temporary housing zones in case of earthquakes, various mining activities and transportation projects. In this connection, the total agricultural land which was used for nonagricultural purposes was 44,500 hectares in $2011 ; 22,400$ hectares of which were assigned to industrial sites, 12,400 hectares to housing zones, 7,900 hectares to mining activities, 1,200 hectares to tourist facilities and 650 hectares to transportation projects [2]. However, fragmentation of agricultural land in Turkey is mainly caused by inheritance and the law of soil protection could not be a solution to this problem. For this purpose, a new law came into force on May 15th, 2014 to prevent fragmentation of agricultural land. This new law not only regulates the sharing of agricultural land in case of inheritance, but also defines minimum sizes of agricultural land. Agricultural land that is inherited cannot be divided to smaller parcels than the size defined by the law and the law endeavors the agricultural land to be left to one inheritor, to a partnership of family property or to be sold to a third person [7].

\subsection{High Costs of Agricultural Inputs}

Agricultural activities cannot be done without the contribution of agricultural inputs, such as seed, fertilizer, diesel oil and fodder. In this respect, it is a must that agricultural inputs are affordable. However in Turkey, such inputs get more expensive each year, leading to more farmers to give up agricultural activities.

\subsubsection{Seed prices}

Since the worldwide agriculture focuses more on higher productivity and longer shelf life of agricultural products, seeds that meet these criteria became more important in the recent past. Such seeds are called improved or hybrid seeds and "they result from crossbreeding two parent plants that have desirable traits" [8].

However, improved seeds have some disadvantages. It is not possible to use an improved seed more than a year since both the productivity and the quality of agricultural produce will decrease in the following years. Therefore, farmers should rebuy them every year. As a result, countries which neither have nor develop the technology of seed improvement should make high amounts of payments to import them. Moreover, the preference of these seeds by farmers may cause local seeds to be lost unless they are protected in "seed banks" [4].

Examining Table 5, the seeds of chick peas were produced the most and they were followed by the seeds of potato, sunflower and maize. Despite the fact that potato, sunflower and maize seeds have an important role in Turkey's seed production, Turkey has to import their parent seeds first to be able to produce the improved seeds. Holland, France, Germany and the USA are the countries from which Turkey usually imports these seeds [4].

Table 3. The distribution of agricultural enterprises and their parcels in Turkey (According to the size of agricultural enterprise)

\begin{tabular}{lll}
\hline $\begin{array}{l}\text { Size of the enterprise } \\
\text { (in hectare) }\end{array}$ & Total number of agricultural enterprises & Total number of parcels \\
\hline Less than 5 & $1,959,123$ & $6,438,682$ \\
$5-20$ & 887,412 & $4,717,267$ \\
$20-50$ & 153,685 & 997,015 \\
More than 50 & 21,907 & 170,441 \\
Total & $3,022,127^{*}$ & $12,323,405$ \\
\hline \multicolumn{2}{c}{ Source: [5] }
\end{tabular}

Table 4. Average land size of agricultural enterprises in Turkey (According to the result of agricultural Census)

\begin{tabular}{lll}
\hline $\begin{array}{l}\text { Total area } \\
\text { (in hectare) }\end{array}$ & $\begin{array}{l}\text { Total number of agricultural } \\
\text { enterprises* }\end{array}$ & $\begin{array}{l}\text { Average land size of agricultural } \\
\text { enterprise (in hectare) }\end{array}$ \\
\hline $18,434,823$ & $3,022,127$ & 6.1 \\
\hline \multicolumn{3}{c}{ Agricultural enterprises without agricultural land are not included. } \\
Source: [2]
\end{tabular}


Table 5. Seed production of selected products in Turkey between 2010 and 2014 (in ton)

\begin{tabular}{lllllll}
\hline & $\mathbf{2 0 1 0}$ & $\mathbf{2 0 1 1}$ & $\mathbf{2 0 1 2}$ & $\mathbf{2 0 1 3}$ & $\mathbf{2 0 1 4}$ & $\begin{array}{l}\text { Change in quantity } \\
\text { between 2010-2014 (\%) }\end{array}$ \\
\hline Maize & 35,234 & 31,338 & 32,796 & 38,576 & 66,578 & 89 \\
Sunflower & 11,854 & 14,137 & 14,732 & 18,756 & 23,769 & 101 \\
Sainfoin & 56 & 200 & 2 & 12 & 46 & -18 \\
Sorghum & 180 & 6 & 12 & 24 & 80 & -56 \\
Fodder Beet & 26 & 33 & 44 & 8 & 5 & -81 \\
Potato & 70,654 & 96,295 & 185,485 & 150,908 & 163,269 & 131 \\
Chick Peas & 253 & 309 & 1,239 & 1,603 & 1,726 & 582 \\
\hline \multicolumn{5}{c}{ Source: $[9]$}
\end{tabular}

According to Table 6 showing seed prices, the highest price increases occurred in sorghum, fodder beet, potato and sainfoin respectively. Sorghum, fodder beet and sainfoin are the three products whose production amounts decreased the most in 2010-2014 period. On the other hand, potato has a different situation since its production amount increased above $100 \%$. This result can be attributed to the fact that Turkey has to import the parent seeds of potato in order to produce its own seeds.

\subsubsection{Prices of chemical fertilizers}

The types of chemical fertilizers that are used in Turkey can be collected in two groups. The first group contains nitrogen as the basic nutrient and includes urea, CAN (calcium ammonium nitrate) and A.S. (ammonium sulfate). Since the agricultural land in Turkey does not contain enough nitrogen [2], "CAN \% 26" is the fertilizer which is used the most. There is also a second group of mixed fertilizers which contain two or more types of nutrients. DAP (diammonium phosphate) and 20.20 .0 belong to this group [11]. With respect to Table 7, the total amount of fertilizer consumption increased $10 \%$ between 2010 and 2014.

On the other hand, price increases in chemical fertilizers range from $55 \%$ to $82 \%$ and the highest price increase belongs to the most used fertilizer.

\subsubsection{Price of diesel oil}

Diesel oil is the fuel which is used in agricultural machinery like tractors and combine harvesters. Therefore, it has a critical contribution to the cost of agricultural produce. The calculation of the selling price of diesel oil in Turkey is as follows:

Price $A=$ Ex-refinery price of diesel oil Price $A+$ Special Consumption Tax $=$ Price $B$ Price $B \times$ Value-Added Tax $=$ Value $X$

Price $B+$ Value $X=$ Selling Price of Diesel Oil

Table 6. Seed Prices of selected products in Turkey between 2010 and 2014 (TL per ton)

\begin{tabular}{lllllll}
\hline Products & $\mathbf{2 0 1 0}$ & $\mathbf{2 0 1 1}$ & $\mathbf{2 0 1 2}$ & $\mathbf{2 0 1 3}$ & $\mathbf{2 0 1 4}$ & $\begin{array}{l}\text { Change in price in } \\
\mathbf{2 0 1 0 - 2 0 1 4} \text { period (\%)* }\end{array}$ \\
\hline Maize & 10,300 & 13,000 & 15,800 & 12,730 & 16,011 & 56 \\
Hybrid Sunflower & 24,250 & 22,500 & 30,880 & 31,020 & 30,590 & 26 \\
Sainfoin & 2,400 & 3,000 & 4,170 & 5,000 & 4,867 & 103 \\
Sorghum & 2,350 & - & 5,750 & 67,600 & 8,250 & 251 \\
Fodder Beet & 8,750 & - & 18,790 & 18,310 & 19,497 & 123 \\
Potato & 1,000 & 1,250 & 1,670 & 1,500 & 2,083 & 108 \\
Chick Peas & 3,000 & 5,000 & 5,660 & 4,970 & 5,042 & 68 \\
\hline \multicolumn{7}{c}{${ }^{*}$ Own calculation source:[6] } \\
\end{tabular}

Table 7. Consumption amounts of chemical fertilizers in Turkey between 2010 and 2014

\begin{tabular}{lllllll}
\hline & 2010 & 2011 & 2012 & 2013 & 2014 & $\begin{array}{l}\text { Change in consumption } \\
\text { between 2010-2014 (\%) }\end{array}$ \\
\hline $\begin{array}{l}\text { Consumption } \\
\begin{array}{l}\text { amounts } \\
\text { (in ton) }\end{array}\end{array}$ & $4,968,058$ & $4,766,356$ & $5,339,893$ & $5,813,612$ & $5,471,518$ & 10 \\
\hline
\end{tabular}

${ }^{\star}$ Own calculation source: [6] 
There are two types of taxes on the selling price of diesel oil. Special consumption tax has a constant value whereas the value-added tax is also constant at $18 \%$. Due to the method of calculation, there exists the situation of "taxation of the tax itself" and the total tax on the selling price of diesel oil corresponds to $50 \%$. The selling price of diesel oil in Turkey increased $47 \%$ between 2010 and 2014.

\subsection{Intermediation System in Turkish Agriculture}

Intermediation system in agriculture which can be described as the marketing of agricultural produce by traders is another major and unending problem in Turkey. Turkish farmers usually prefer to sell their products to traders instead of marketing their agricultural produce themselves. As a result, farmers consent to the prices paid by the traders and cannot earn a living from agriculture.

Table 10 summarizes the producer, weekly market and market prices of selected agricultural products between 2010 and 2014. As the table shows, the market prices of agricultural products are usually higher than the weekly market prices. However, there are huge price differences among producer, weekly market and market prices. For instance, the difference between producer and weekly market prices ranges from $30 \%$ to $300 \%$ while the difference between producer and market prices ranges from $53 \%$ to $383 \%$. In other words, agricultural produce is bought at cheap prices from Turkish farmers to be sold at high prices to Turkish consumers. In conclusion, this system of intermediation in Turkish agriculture is only on behalf of traders.

\subsection{Lack of Farmer Education, Agricultural Research and Advisory System in Turkey}

When the direct effects of agriculture on both human health and environment are taken into account, educating farmers becomes more important. However, farmer education in Turkey is still inadequate. Since Turkish farmers usually live in rural areas and they are economically incapable of sending their children to universities that are located in the city centers, the majority of them are only graduates of a primary or a secondary school. The number of farmers to attend a university is quite low in Turkey [15].
The inadequacy of farmer education in Turkey becomes visible in two topics, one of which is the application of pesticides and the other is the pesticide residues. The problems related to the application of pesticides can be summarized as the choice of a pesticide as well as the dose and timing of its application. A survey that was conducted in Konya province of Turkey revealed that farmers preferred to choose pesticides and decide their doses and timing of application by obtaining information from pesticide dealers in the first place. However, the pesticide dealers in Turkey range from primary school graduates to people who have professions other than agriculture. In this regard, such people cannot guide farmers correctly. Besides, Turkish farmers also decide by benefiting from their past experiences. The number of Turkish farmers who choose to be informed by agronomists is really low in either case [15]. Pesticide residues are another serious problem in Turkey. Many Turkish farmers do not have any information about the health and environmental hazards of pesticides. They have a tendency to think that pesticide residues are lost by rain or by washing so that there aren't any residues. Most of the Turkish farmers do not have an idea about the pesticide residue-cancer relationship. They think that pesticide residues neither affect human health negatively, nor cause illnesses. The situation gets even worse in case of pesticide residueenvironment relationship. Many Turkish farmers scatter around empty pesticide containers randomly, bury them in the ground, burn them or even wash and reuse them [15].

In this connection, an agricultural advisory system which is combined with agricultural research becomes more important. The agricultural advisory system in Turkey is totally based on private agricultural advisors. These advisors can either be employed by agricultural advisory companies, producer organizations and agricultural chambers or work independently. The state is responsible from controlling their activities and preparing examinations for awarding certificates. As a consequence, only farmers who have production with contract, are members of a producer organization and agricultural chamber and are financially powerful can benefit from the agricultural advisory system in Turkey [16].

On the other hand, agricultural research in Turkey is not where it should be. An agricultural university which only focuses on various agricultural faculties does not exist in Turkey. 
Instead, agriculture in Turkey is still taught in a schools [17] and in the agricultural faculties of limited number of agricultural vocational high some universities.

Table 8. Average prices of chemical fertilizers in Turkey between 2010 and 2014 (TL per ton)

\begin{tabular}{|c|c|c|c|c|c|c|}
\hline $\begin{array}{l}\text { Type of } \\
\text { fertilizer }\end{array}$ & $2010^{*}$ & 2011* & $2012^{*}$ & 2013* & 2014* & $\begin{array}{l}\text { Change in price } \\
\text { between } \\
2010-2014(\%) \text { ** }\end{array}$ \\
\hline A.S. \% 21 & 347 & 532 & 583 & 566 & 564 & 63 \\
\hline CAN \% 26 & 439 & 561 & 692 & 739 & 799 & 82 \\
\hline A.N. \% 33 & 531 & 678 & 800 & 836 & 891 & 68 \\
\hline Urea & 631 & 893 & 1,071 & 1,018 & 1,045 & 66 \\
\hline DAP & 919 & 1,362 & 1,332 & 1,209 & 1,425 & 55 \\
\hline 20.20 .0 & 617 & 964 & 958 & 873 & 965 & 56 \\
\hline
\end{tabular}

Table 9. Average prices of diesel oil in Turkey in 2010-2014 period

\begin{tabular}{lcccccl}
\hline & $\mathbf{2 0 1 0}$ & $\mathbf{2 0 1 1}$ & $\mathbf{2 0 1 2}$ & $\mathbf{2 0 1 3}$ & $\mathbf{2 0 1 4}$ & $\begin{array}{l}\text { Change in price in 2010-2014 } \\
\text { period (\%)* }\end{array}$ \\
\hline $\begin{array}{l}\text { Average prices of diesel } \\
\text { oil (TL per liter) }\end{array}$ & 2.97 & 3.57 & 3.84 & 4.26 & 4.36 & 47 \\
\hline
\end{tabular}

Table 10. Prices of selected fruit and vegetables in Turkey (TL per kg)

\begin{tabular}{|c|c|c|c|c|c|}
\hline & & $\begin{array}{l}\text { Apple } \\
\text { (Starking) }\end{array}$ & $\begin{array}{l}\text { Mandarin } \\
\text { (Satsuma) }\end{array}$ & Tomato & Potato \\
\hline \multirow[t]{5}{*}{2010} & Producer price & 1.04 & 0.80 & 1.00 & 0.62 \\
\hline & Weekly market price & 1.41 & 1.69 & 1.69 & 0.85 \\
\hline & Market price & 1.88 & 1.98 & 1.87 & 0.95 \\
\hline & $A^{*}$ & $36 \%$ & $111 \%$ & $69 \%$ & $37 \%$ \\
\hline & $\mathrm{B}^{* *}$ & $81 \%$ & $148 \%$ & $87 \%$ & $53 \%$ \\
\hline \multirow[t]{5}{*}{2011} & Producer price & 1.27 & 0.84 & 0.77 & 0.7 \\
\hline & Weekly market price & 2.63 & 2.33 & 1.64 & 0.91 \\
\hline & Market price & 3.03 & 2.98 & 1.74 & 1.17 \\
\hline & $A^{* * *}$ & $107 \%$ & $177 \%$ & $113 \%$ & $30 \%$ \\
\hline & $\mathrm{B}^{* * *}$ & $139 \%$ & $255 \%$ & $126 \%$ & $67 \%$ \\
\hline \multirow[t]{5}{*}{2012} & Producer price & 1.08 & 0.86 & 0.80 & 0.47 \\
\hline & Weekly market price & 1.96 & 2.50 & 1.66 & 0.93 \\
\hline & Market price & 2.46 & 2.78 & 1.93 & 0.87 \\
\hline & A & $82 \%$ & $191 \%$ & $108 \%$ & $98 \%$ \\
\hline & $\mathrm{B}$ & $128 \%$ & $223 \%$ & $141 \%$ & $85 \%$ \\
\hline \multirow[t]{5}{*}{2013} & Producer price & 0.96 & 0.66 & 0.77 & 0.56 \\
\hline & Weekly market price & 2.58 & 2.19 & 2.55 & 1.19 \\
\hline & Market price & 2.54 & 3.19 & 2.82 & 1.52 \\
\hline & A & $169 \%$ & $232 \%$ & $231 \%$ & $113 \%$ \\
\hline & $\mathrm{B}$ & $165 \%$ & $383 \%$ & $266 \%$ & $171 \%$ \\
\hline \multirow[t]{5}{*}{2014} & Producer price & 1.09 & 0.63 & 0.80 & 1.16 \\
\hline & Weekly market price & 4.36 & 1.71 & 2.38 & 1.78 \\
\hline & Market price & 3.27 & 2.51 & 2.56 & 2.22 \\
\hline & A & $300 \%$ & $171 \%$ & $198 \%$ & $54 \%$ \\
\hline & B & $200 \%$ & $298 \%$ & $220 \%$ & $91 \%$ \\
\hline
\end{tabular}

${ }^{*}$ A shows the difference between producer and weekly market prices as a percentage.

${ }^{* *} B$ shows the difference between producer and market prices as a percentage; ${ }^{* * *}$ Own calculations Source: Producer prices are taken from [12-14] while weekly market and market prices are taken from [10] 


\subsection{Insufficient Financial Support for Turkish Agriculture}

Financial support is not only an important factor in planning the agricultural production of a country, but also a good indicator of a government's point of view of towards agriculture. Area based support, support for growing forage crops, deficiency, compensatory and other agricultural payments are the main types of financial support paid to Turkish farmers. The main criterion to be able to benefit from these support types is to be registered under the System of Farmer Registration.

The amount of financial support that is paid to each item increased in variable rates between 2010 and 2014 as shown in Table 11. Despite this situation, the increases in area based support and support for forage crops made no progress when the price increases in seed, diesel oil and chemical fertilizer were taken into consideration in the same period [18].

Table 11. Type of financial support in Turkey in 2010-2014 period (million TL)

\begin{tabular}{lllllll}
\hline & $\mathbf{2 0 1 0}$ & $\mathbf{2 0 1 1}$ & $\mathbf{2 0 1 2}$ & $\mathbf{2 0 1 3}$ & $\mathbf{2 0 1 4}$ & $\begin{array}{c}\text { Change in 2010 - } \\
\text { 2014 period (\%)* }\end{array}$ \\
\hline Area based support 1 & 1,859 & 1,996 & 2,158 & 2,189 & 2,406 & 29 \\
Support for forage crops 2 & 253 & 293 & 294 & 311 & 334 & 32 \\
Deficiency payments 3 & 2,072 & 2,503 & 2,379 & 2,641 & 2,481 & 20 \\
Compensatory payments 4 & 77 & 82 & 99 & 112 & 121 & 57 \\
Other agricultural payments $\mathbf{5}$ & 113 & 121 & 165 & 149 & 177 & 57 \\
\hline
\end{tabular}

1 Area based agricultural support includes support payments for diesel oil, chemical fertilizers, soil

analysis, organic farming and good agricultural practices, growing alternative products as well as income support for hazelnut growers.; 2Farmers who grow forage crops in an area of at least 10 decares can benefit from this support. 3Deficiency payments will be made for 16 products that are grown in 30 agricultural basins determined by the Turkish

Ministry of Food, Agriculture and Livestock. 4This support will be paid to hazelnut and tea growers as well as potato growers who fight with a specific potato disease. 5Other agricultural support will be paid to producers who use certificated seeds and sapling produced domestically, who produce certificated seeds in Turkey, who take advice from qualified agronomists and who attend the programme of protecting agricultural land for environmental purposes.; Own Calculations

Source: Explanations of support types are taken from [19] and the rest are taken from [6]

Table 12. Possible effects and results of climate change in Turkey

\begin{tabular}{ll}
\hline Effects of climate change on soil & $\begin{array}{l}\text { Possible results of climate change on } \\
\text { Turkish agriculture }\end{array}$ \\
\hline Change in the pH value of soil & "The life and growth of plants will be directly affected." \\
& $\begin{array}{l}\text { As a result, there will be the need to apply special } \\
\text { materials or chemical fertilizers to readjust the pH value } \\
\text { of soil [21]. }\end{array}$ \\
\hline Increase in the amount of precipitation & 1- Soil will become more humid, increasing the activities \\
& of pests in soil and spread of diseases. \\
& 2- Excess rainfall will either cause soil erosion or \\
increase its severity. & 3- Black Sea Region will receive more precipitation. \\
\hline Decline in the amount of rainfall and increase in & 1- The salinisation and desertification of soil will \\
the levels of evapotranspiration & increase in semi arid regions of Turkey. \\
& 2- Mediterranean Region will receive less rainfall. \\
3- Evapotranspiration will be at the highest levels in & Marmara, Mediterranean, Central Anatolia and \\
& Southeastern Anatolia regions. \\
4-Water demand will increase in dry regions.
\end{tabular}

Extreme weather events, such as frost, hail and The amount of vegetable and fruit production will whirlwinds will be seen more frequently. decrease.

Agricultural produce will be completely different. It will be impossible to grow some of the Agricultural products that were grown before. However, new products like the tropical ones will start to be grown. Source: [2,22] 


\subsection{Possible Effects of Climate Change on Turkish Agriculture}

Climate change is an issue which receives more global attention each day. Even though Turkey is a country where three different types of climate facilitate the growth of many agricultural products, global climate change will change this characteristic of Turkey. A worldwide increase of 2 degrees will correspond to a shift in Turkey's climate from "temperate- subtropical zone" to "semi arid -tropical zone". A sudden increase in the amount of rainfall in a specific location in a short time despite no change in annual rainfall, floods, more powerful storms, frequent repetitions of whirlwinds that were rarely seen before and droughts in dry regions are all signs of a "semi arid" and "tropical" climate. In other words, Turkey is on the way to become a country where four seasons are seen to a country with only two seasons; a hot summer and a mild or a colder winter [20]. A shift in climate will definitely have sharper results on the agricultural activities of Turkey as expressed in Table 12.

\section{CONCLUSION AND RECOMMENDA- TIONS}

The decline in total agricultural land is one of the top issues of Turkish agriculture caused by using agricultural land for non-agricultural purposes along with the misuse of agricultural land. Regarding the use of agricultural land for nonagricultural purposes, a countrywide plan organizing land use in Turkey should be prepared by the state as soon as possible. Such a plan should briefly describe which piece of land will be assigned for agricultural activities, industrial areas, housing zones etc. Besides, the state should take all the measures to prevent illegal housing on agricultural land in Turkey [4].

A second problem is the fragmentation of agricultural land in Turkey. The state can handle this problem by continuing the activities of land consolidation that were initiated in 1961 [2]. On the other hand, there can also be other precautions to prevent fragmentation. For instance, the Turkish state can reduce the inheritance tax to endeavor agricultural land to be left to one inheritor as it is in Denmark and support the establishment of land banks as in the example of France [2]. Land banks are non-profit organizations working for the public weal. They are established by the coming together of producer and professional organizations beside other legal entities related to agriculture on a regional scale. Their main duty is to buy agricultural land sold by its owner to sell it to other agricultural producers who either want to enlarge their enterprises or are landless. However, a land bank must sell agricultural land only to another agricultural producer and in a specific period of time [2].

High costs of agricultural inputs are another problem in Turkey. Financially supporting the expensive and time taking, research and development phase of seed improvement and remitting special consumption \& value added taxes on the sales price of diesel oil, can all be implemented by the state to solve the problem of expensive inputs. However, financial support in agriculture should always be updated according to the price increases in agricultural inputs.

With respect to the intermediation system in agricultural produce, it will be the best for farmers to establish agricultural development cooperatives and direct sales channels like weekly producer markets. Thus, farmers will have bargaining power and determine the sales prices of their products themselves [1].

Furthermore, the lack of an agricultural research and advisory system as well as farmer education is another source of constraint in Turkey. As regards agricultural research, there is the need for a university of agricultural sciences in Turkey. Besides, the number and the educational quality of agricultural vocational high schools should also be increased. On the other hand, an agricultural advisory system where the state itself also employs agronomists in addition to private advisors should also be established. Turkish farmers must be educated about the negative results of land misuse in addition to the health and environmental hazards of pesticide residues by agronomists. In the meantime, the state should also regulate pesticide dealers. New people who will work as pesticide dealers should fulfill the condition of "being graduated from relevant agricultural faculties" while existing pesticide dealers who do not have such an agricultural background should be trained by agronomists [15].

Finally, climate change is a danger that is waiting at the door of Turkey. Even though many countries have already started to prepare special plans showing the possible effects of climate change on agriculture and how to cope with them on a regional and countrywide basis, such a plan does not exist for Turkey. Turkish farmers do not 
have an idea of what will happen when climatic conditions change. Therefore, the priority in Turkish agricultural policy should be given to climate change and detailed plans about the effects of climate change on Turkish agriculture should be prepared as soon as possible.

\section{COMPETING INTERESTS}

Author has declared that no competing interests exist.

\section{REFERENCES}

1. Aydemir C, Picak M. The effects of relations between agriculture and industry on intersectoral integration during economic development. D. U. Ziya Gokalp Egitim Fakultesi Dergisi. 2008;10:129-147. Available:http://www.zgefdergi.com/DergiP dfDetay.aspx?ID=136

(Accessed: 12 September 2015)

2. Turkish Ministry of Development. The study group report for sustainable use of agricultural land; 2014.

Available:http://tarim.kalkinma.gov.tr/wp c ontent/uploads/2014/12/Tarim Arazilerinin Surdurulebilir Kullanimi Calisma Grubu Raporu.pdf

(Accessed: 23 August 2015)

3. Turkish Statistical Institute. Agricultural land and forest area; 1998-2014. Available:http://www.tuik.gov.tr/Prelstatistik Tablo.do?istab id=53

(Accessed: 10 September 2015)

4. The Union of Turkish Agricultural Chambers. Agricultural and Economic Report; 2007-2010.

Available:http://www.tzob.org.tr/Portals/0/D okumanlar/ZirailktisadiRaporlar/Zirairapor2 007-2010.zip

(Accessed: 21 August 2015)

5. Turkish Statistical Institute. Number of agricultural enterprises, parcels and land size according to the size of agricultural enterprises and number of parcels. Available:http://www.tuik.gov.tr/Prelstatistik Tablo.do?istab id=293

(Accessed: 1 September 2015)

6. Turkish Ministry of Food, Agriculture and Livestock. Directorate general for plant production; 2015.

Available:http://www.tarim.gov.tr/sgb/Belge ler/SagMenuVeriler/BUGEM.pdf

(Accessed: 23 August 2015)
7. Law amending the law of soil protection and land use. Official Journal. Number 29001.

Available:http://www.resmigazete.gov.tr/es kiler/2014/05/20140515-1.htm

(Accessed: 8 October 2015)

8. Cho Renee. Improving seeds to meet future challenges. Earth Institute, Columbia University.

Available:http://blogs.ei.columbia.edu/2013 /02/08/improving-seeds-to-meet-futurechallenges/

(Accessed: 6 October 2015)

9. Turkish Ministry of Food, Agriculture and Livestock. Seed Production.

Available:http://www.tarim.gov.tr/BUGEM/ Belgeler/Bitkisel\%20Üretim/Tohumculuk/İs tatistikler/ tohumlukuretim yıllara gore.pdf

(Accessed: 8 October 2015)

10. Turkish Ministry of Food, Agriculture and Livestock. The Institute of Agricultural Economics and Policy Making. Agricultural data; 2015.

Available:http://www.tarim.gov.tr/Belgeler/ SagMenuVeriler/TarimsalVeriler.pdf (Accessed: 2 September 2015)

11. Chemical Fertilizers, Mixed Fertilizers and Their Uses. Istanbul Gubre Sanayii AS. Available:http://www.igsas.com.tr/tr/default .asp?rsm=141511000000\&Kimyevi-Gubreve-Kullanimi

(Accessed: 8 October 2015)

Available:http://www.igsas.com.tr/tr/default .asp?rsm=141512100000\&Kompoze

Gubre

12. Turkish Statistical Institute. Producer prices of vegetables.

Available:http://www.tuik.gov.tr/Prelstatistik Tablo.do?istab id=698

(Accessed: 13 September 2015)

13. Turkish Statistical Institute. Producer prices of fruit.

Available:http://www.tuik.gov.tr/Prelstatistik Tablo.do?istab id=699

(Accessed: 12 September 2015)

14. Turkish Statistical Institute. Prices of crops and others.

Available:http://www.tuik.gov.tr/Prelstatistik Tablo.do?istab id=697

(Accessed: 13 September 2015)

15. Kalipci E, Ozdemir C, Oztas H. A survey on the knowledge level and environmental awareness of farmers about pesticide use. TUBAV Bilim Dergisi. 2011;3:179-187. 
Available:http://dergipark.ulakbim.gov.tr/tu bav/article/view/1013000141

(Accessed: 22 August 2015)

16. Turkish Ministry of Food, Agriculture and Livestock. The regulation for agricultural advice and extension services.

Available:http://www.tarim.gov.tr/EYYDB/B elgeler/TDYH/yonetmelik.pdf

(Accessed: 16 October 2015)

17. Agricultural Vocational High Schools. Available:http://mebk12.meb.gov.tr/meb iy s dosyalar/.../08020849 tarımmeslek.pdf (Accessed: 6 November 2015)

18. Yildirim Ali Ekber. Prices of agricultural inputs.

Available:http://www.tarimdunyasi.net/?p= $\underline{2420}$

(Accessed: 2 September 2015)

19. Agricultural Support. Zafer Development Agency.
Available:http://www.zafer.org.tr/desteklertesvikler/diger-destekler-tesvikler-

hakkinda-genel-bilgi/227- milli-emlakgenel-mudurlugu-destekleri.html

(Accessed: 18 October 2015)

20. Sen Orhan. Seasonal characteristics of turkey are changing. Milliyet. Available:http://www.milliyet.com.tr/turkiye-nin-mevsim-ozellikleri-gundem2046052

(Accessed: 17 October 2015)

21. Vossen Paul. Changing $\mathrm{Ph}$ in Soil. Available:http://vric.ucdavis.edu/pdf/Soil/C hangingpHinSoil.pdf (Accessed: 22 October 2015)

22. Saylan Levent. Potential impacts of climate change on agriculture in Turkey. Available:http://www.cost734.eu/reportsand-presentations/7th-managementcommittee-meeting (Accessed: 20 August 2015)

(C) 2016 Ozbilge; This is an Open Access article distributed under the terms of the Creative Commons Attribution License (http://creativecommons.org/licenses/by/4.0), which permits unrestricted use, distribution, and reproduction in any medium, provided the original work is properly cited.

Peer-review history:

The peer review history for this paper can be accessed here: http://sciencedomain.org/review-history/14617 